Chapman University

Chapman University Digital Commons

Business Faculty Articles and Research

Business

$10-2011$

\title{
Testing the Waters: Using Collective Real Options To Manage the Social Dilemma Of Strategic Alliances
}

\author{
Matthew McCarter \\ Chapman University \\ Joseph T. Mahoney \\ University of Illinois \\ Gregory B. Northcraft \\ University of Illinois
}

Follow this and additional works at: https://digitalcommons.chapman.edu/business_articles

Part of the Organizational Behavior and Theory Commons

\section{Recommended Citation}

Mccarter, Matthew W., Joseph T. Mahoney, and Gregory B. Northcraft. "Testing the Waters: Using Collective Real Options to Manage the Social Dilemma of Strategic Alliances." The Academy of Management Review 36.4 (2011): 621-40.

DOI:10.5465/amr.2009.0481

This Article is brought to you for free and open access by the Business at Chapman University Digital Commons. It has been accepted for inclusion in Business Faculty Articles and Research by an authorized administrator of Chapman University Digital Commons. For more information, please contact laughtin@chapman.edu. 


\section{Testing the Waters: Using Collective Real Options To Manage the Social Dilemma Of Strategic Alliances}

\section{Comments}

This article was originally published in The Academy of Management Review, volume 36, issue 4, in 2011. DOI: 10.5465/amr.2009.0481

\section{Copyright}

Academy of Management 


\title{
TESTING THE WATERS: USING COLLECTIVE REAL OPTIONS TO MANAGE THE SOCIAL DILEMMA OF STRATEGIC ALLIANCES
}

\author{
MATTHEW W. MCCARTER \\ Chapman University \\ JOSEPH T. MAHONEY \\ GREGORY B. NORTHCRAFT \\ University of Illinois at Urbana-Champaign
}

\begin{abstract}
We extend real options research by introducing the concept of collective real options and model how collective real options provide strategic alliances a mechanism to manage social uncertainty. Collective real options manage social uncertainty by producing relational small wins that develop trust. The amount of trust developed by acquiring a collective real option depends on the exposure of alliance partners. Alliance partner reputation also plays an important role in the impact of collective real options.
\end{abstract}

Strategic alliances are "voluntary arrangements [among two or more organizations] involving the exchange, sharing, or co-development of products, technologies, or services" (Gulati, 1998: 293) and are a means for organizations to achieve goals they could not attain independently. Alliances create value through the pooling of resources to provide alliance partners with competitive advantages over rivals (Das \& Teng, 2000; Hardy, Phillips, \& Lawrence, 2003). However, alliances often fail to create their anticipated benefits (Gottschalg \& Zollo, 2007; Kale, Dyer, \& Singh, 2002). This article examines how the use of real options can influence the likelihood of alliance success.

Two critical factors influencing alliance success are environmental uncertainty and social uncertainty. Environmental uncertainty stems from a lack of information about the market and task environment (Bowman \& Hurry, 1993; Das \& Teng, 1996). As a consequence of environmental uncertainty, alliance partners may fear that their pooled investments will not yield a sufficiently profitable return (McCarter, Rockmann, \& Northcraft, 2010), and they may therefore protect their own interests at the expense of the alliance (Luo, 2007). Social uncertainty stems

We express our appreciation to associate editor Jean Philippe-Bonardi and three anonymous reviewers for their input and suggestions. from a lack of information about the intentions of alliance partners, and it impedes interfirm cooperation because alliance partners may fear they cannot trust each other to do what is best for the alliance (Messick, Allison, \& Samuelson, 1988; Park \& Ungson, 2001). This lack of trust pushes alliance partners to either underinvest defensively or not enter into the alliance altogether, thereby missing opportunities to capitalize fully on alliance potential (McCarter \& Northcraft, 2007).

For the past two decades, real options research on uncertainty in alliance governance (Kogut, 1991) has focused on understanding how alliance partners use real options unilaterally to manage environmental uncertainty (Folta, 1998; Reuer \& Tong, 2005). We develop a model of how real options can be used collectively to manage social uncertainty among alliance partners, thereby enhancing the likelihood of alliance success. The core logic of our model comes in five parts: (1) large-scale alliance cooperation represents a social dilemma requiring trust, (2) collective real options offer alliance partners the opportunity to achieve relational small wins that increase trust, (3) increased trust decreases the perceived vulnerability among alliance partners and, thus, fuels larger-scale alliance cooperation, (4) exposure (the amount of resources put at risk by alliance partners to acquire the collective real option) moderates the effect of a relational small win on trust develop- 
ment, and (5) the reputations of alliance partners also play an important role in the impact of collective real options.

Examining how collective real options influence social uncertainty in alliances helps bridge the (often independently studied) structural and motivational approaches to alliance governance. In doing so our conceptualization of real options highlights the importance of social uncertainty-and its management via the psychology of relational small wins-to alliance success.

We begin by first reviewing essential elements of the social dilemma paradigm. Next, we introduce the concept of collective real options as a hybrid approach to managing social uncertainty in alliances. We then propose a model capturing how collective real options influence trust formation in alliances. We conclude by discussing the theoretical and managerial implications of our model.

\section{STRATEGIC ALLIANCE SOCIAL DILEMMAS: A BRIEF REVIEW}

The social dilemma paradigm has proven very useful in helping understand how social uncertainty influences cooperation among alliance partners (Zeng \& Chen, 2003). A social dilemma, broadly defined, is a situation in which it appears that being uncooperative can be personally beneficial at the collective's expenseunless everyone else in the collective also chooses to be uncooperative, in which case no one benefits (Liebrand, 1983). In strategic alliances partners' resources can be pooled to create a public good-that is, a resource that, once produced, is enjoyed by all alliance partners, whether they contributed or not (Olson, 1965). For instance, a group of firms may pool resources to identify more efficient recycling processes (Tirole, 1996). ${ }^{1}$ When an alliance partner

\footnotetext{
${ }^{1}$ Public goods come in two forms (Cornes \& Sandler, 1996). Pure public goods are resources available to anyone in a society or similar large-scale collective-for example, a nation, community, or city. Examples of pure public goods include public radio, national defense, and lighthouses. Private public goods (or club goods) are resources available to anyone within a smaller-scale collective, such as a strategic alliance. Examples of private public goods include new technologies and processes developed in strategic alliances and generic advertising campaigns (e.g., "Got milk?" and "Beef, it's what for dinner!") used in a particular industry. In
}

contributes private resources to further the alliance's interest-such as contributing people or capital to identify more efficient recycling processes-this action is termed cooperation (Dawes, 1980). Defection occurs when an alliance partner fails to contribute (or underinvests) private resources toward alliance initiatives (Dawes, 1980).

An alliance partner might underinvest in alliance initiatives for two reasons. First, an alliance partner may attempt to "free ride"-enjoy the created public good (e.g., more efficient recycling processes) without contributing toward its creation. In other words, offensive defection occurs when an alliance partner attempts to enjoy the shored benefit without incurring much (if any) cost (Zeng \& Chen, 2003). Alternatively, an alliance partner may defensively defectunderinvest or, in the extreme, not contribute at all-to avoid wasting resources if the alliance partner believes others also will underinvest (Rockmann \& Northcraft, 2008). Unfortunately, if enough alliance partners underinvest, regardless of whether offensively or defensively, the public good is not produced and no alliance partners benefit-for example, poor air quality abounds and alliance resources are wasted (Messick \& Brewer, 1983). We focus on defensive defection here because even if measures are taken to make offensive defection impossible, an alliance partner may remain suspicious of other alliance partners' intentions and thereby defect defensively to avoid wasting personal resources (McCarter \& Northcraft, 2007). ${ }^{2}$

\footnotetext{
this second instance the private public good is public to $a$ smaller specified collective (e.g., alliance partners) while being privatized from a larger specified collective (e.g., the entire populace of a city). While our propositions are not limited to either form of public good, in this article we refer to examples of private public goods, and we use the abbreviated term public good to remain consistent with the types of public goods discussed in the literature on strategic alliances (Agarwal, Croson, \& Mahoney, 2010; McCarter \& Northcraft, 2007; Zeng \& Chen, 2003).

2 The social dilemma paradigm is complementary to other game-theoretic-based paradigms, such as co-opetition and integrative negotiation. The similarity between the social dilemma paradigm and other game-theoretic paradigms is that value creation occurs through cooperative, collective action. The difference resides in the degree of exclusivity between cooperative and competitive actions. In social dilemmas cooperation and defection are interdependent: an alliance partner cannot defect (or cooperate) without affecting the other alliance partners in negative (or positive) ways
} 
Structural and Motivational Approaches to Strategic Alliance Social Dilemmas

The social dilemma paradigm offers two approaches to managing social uncertainty in alliances: structural and motivational (Kollock, 1998; Zeng \& Chen, 2003). ${ }^{3}$ Both approaches attempt to mitigate social uncertainty by increasing trust among alliance partners, because trust is a central critical factor determining partner investment in alliance initiatives (McCorter \& Northcraft, 2007).

The structural approach seeks to raise alliance partner trust by making defection more costly than cooperation (Hennart, 1988) so that alliance partners will believe no partner has on incentive to defect. Classic structural solutions involve sanctions, such as threatening monetary fines or the spread of bad reputations for defecting alliance partners (Das \& Teng, 2002; Zeng \& Chen, 2003), and contracting, such as relationship-specific investments (Porkhe, 1993), credible commitments (Williamson, 1983), and selfenforcing agreements (Telser, 1980).

The motivational approach attempts to increase trust by altering how alliance partners perceive each other (Dyer \& Singh, 1998; Zaheer \& Venkatraman, 1995) so that they will believe no partner is likely to defect, even if there appears to be an incentive to do so. Traditional motivational solutions entail alliance partners' communicating cooperative intent before joint investments are made (Monge et al., 1998) and

(Kaufman \& Kerr, 1993; Kollock, 1998). The co-opetition paradigm (Brandenburger \& Nalebuff, 1996) and integrative negotiation paradigm (Hoffman et al., 1999) assume that cooperation (or creating value) is independent of defection (or claiming value): individuals acting in their own selfinterests can lead to an outcome that is in everyone's best interests. Thus, whereas co-opetition and integrative negotiation paradigms may be modeled using an invisible-hand game (Miller, 1993), social dilemmas are modeled using nprisoners' (and assurance) dilemma games (Dawes, 1980; Liebrand, 1983).

${ }^{3}$ Other scholarship has used alternative typologies for grouping social dilemma solutions. For example, social psychology and operations management research codify social dilemma solutions as a function of whether solutions are unilateral or jointly implemented (McCarter \& Northcraft, 2007; Messick \& Brewer, 1983). To remain consistent with previous research applying the social dilemma paradigm to alliance management, we delineate solutions as to whether they change how alliance partners perceive either the structure of the alliance or the other exchange partners in the alliance. encouraging alliance partners to consider each other's needs (Spekman, Isabella, MacAvoy, \& Forbes, 1996). For instance, future alliance partners may meet frequently to plan, discuss goals, and communicate intentions before contributing resources toward alliance initiatives (Kanter, 1994; Murray \& Mahon, 1993).

\section{Limitations of Structural and Motivational Approaches}

Both structural and motivational solutions, in isolation, are limited in their ability to encourage cooperation among alliance partners (Lichbach, 1996). Structural solutions are unable to cover every possible free-riding loophole (Williamson, 1979), are only effective "if [they] can be done cheaply enough" (Telser, 1980: 28), and can negatively affect how alliance partners think about the alliance. Regarding this last point, contracting (for example) leads alliance partners to trust the contract rather than each other, leaving the relationship vulnerable when the contract is repealed or a weakness in the contract is found (Malhotra \& Murnighan, 2002; Sitkin \& Roth, 1993). Along these lines, Malhotra and Lumineau's (in press) field study on interfirm contracting shows that when disputes arise, goodwill trust and willingness to continue collaboration among alliance partners decrease as the number of control provisions in the contract increase. As for sanctions, threatening punishment not only alters the payoffs associated with cooperation and defection but also reframes how alliance partners perceive such behaviors. Tenbrunsel and Messick (1999) found that using sanctions to enforce cooperation diverts alliance partner attention from the moral consequences of defection to the economic consequences of being caught defecting. This shift of consideration actually can increase defection.

Motivational solutions alone have limitations as well because of their reliance on verbal reassurances of alliance partner trustworthiness. Absent action, such verbal reassurance may be viewed as "cheap talk," leaving partners still suspicious of each other's actual intent (Crawford, 1998; Farrell \& Rabin, 1996). Further, alliance partners typically believe themselves to be more honest and more cooperative (i.e., more trustworthy) than others, which also fuels suspicion of others and, hence, defensive defection (Epley, Caruso, \& Bazerman, 2006). Indeed, re- 
search on international alliances shows that trust is fostered only after alliance partners confirm their intentions through investment in the alliance (Robson, Katsikeas, \& Bello, 2008).

These findings highlight that neither a structural nor a motivational solution, independently, is sufficient to alleviate social uncertainty in strategic alliance social dilemmas, suggesting the need to identify a governance mechanism that incorporates elements of both solutions (Foddy, Smithson, Schneider, \& Hogg, 1999). Research in strategic management supports this conclusion (Agarwal et al., 2010): a laboratory simulation of cooperation in alliances found that mutual cooperation was highest when both economic incentives were aligned (a structural solution) and communication was allowed among alliance partners (a motivational solution). In this article we introduce collective real options as a hybrid solution that provides a more effective alternative than existing alliance governance mechanisms.

\section{REAL OPTIONS IN STRATEGIC ALLIANCES}

A real option is a right-without an obligation-to invest resources (e.g., labor, money, time) toward a course of action at a future point in time (Dixit \& Pindyck, 1994). Because of the environmental uncertainty inherent in making any investment (Hobfoll, 1998), real options provide an attractive "psychological hedge" in the minds of investors (Bazerman \& Gillespie, 1999; Malhotra, 2005). Real options allow investors to feel less vulnerable to the negative effects of investment failure (Meyerson, Weick, \& Kramer, 1996). Environmental uncertainty is mitigated because real options delay full investment until critical information about the environment (such as market conditions, profitability of a potential investment, and entry of new competitors) can be revealed over time (Bowman \& Hurry, 1993). An example of how real options reduce environmental uncertainty is a university that is considering adoption of a new technology, such as a campus phone system (Ziedonis, 2007). Prior to investing large amounts of resources to roll out the new phone system campus wide, the university can take the real option of field testing the system in one campus building. After the field test, environmental uncertainty is reduced because the university has additional information about how the phone system works, along with the compatibility and benefits of the system.

Real options change the structure of an investment by separating resource allocation into a multistage process, with an option to exit at the conclusion of any stage (Adner \& Levinthal, 2004; $\mathrm{Mu}, 2006)$. While real options take a variety of forms (Trigeorgis, 1999), the focus here is on "time-to-build" real options (also called "growth" or "compound" options), in which on individual firm's investments come in multiple stages (Sing, 2002; Smit \& Trigeorgis, 2004). In the first stage the firm-facing high environmental uncertainty-acquires the real option by investing a small amount of resources, which provides the firm an opportunity to uncover additional information about the environment so as to make more informed later-stage investment decisions. In the later stages the firmhaving learned more about the environmentexercises the option of either investing additional resources or abandoning the venture.

A pilot project represents a time-to-build real option (Ziedonis, 2007). A firm makes an initial investment in a small version of the venture (a pilot project) to see whether further investments might hold promise; the firm then can exercise the real option created by the pilot project by making subsequent larger investments in the venture if the results from the pilot project are favorable (Fawcett, Magnan, \& McCarter, 2008; Kim \& Sanders, 2002). In making the initial smaller investment, the time-to-build real option is acquired. In making the subsequent larger investments, the time-to-build real option is exercised (Li, James, Madhaven, \& Mahoney, 2007).

\section{Collective Real Options}

A collective real option is an action undertaken jointly by alliance partners when all partners agree to make a small initial investment of resources to uncover environmental and social information about the possible success of $\alpha$ subsequent larger-scale alliance initiative. Environmental information refers to factors exogenous to the alliance (such as market forces) that influence the anticipated benefits of collective action (such as revenues and enhonced reputation). Social information refers to factors endogenous to the alliance that influence the anticipated benefits of collective action-specifically, the perceived trustworthiness of the alliance 
partners (Gulati, 1998), including their integrity, reliability, and commitment. Acquiring the collective real option occurs when the alliance partners jointly invest in the small-scale (e.g., pilot project) initiative. This definition highlights two key elements that separate collective real options from traditional conceptualizations of real options and related constructs.

First, traditional research on real options typically has examined how individuals (or individual firms) acquire real options to reduce uncertainty when making investment decisions (Bowman \& Moskowitz, 200l; Folta \& Miller, 2002). However, as Li et al. (2007) suggest, real options may be acquired and exercised by collectives, such as an alliance. Although collective real options are created by the collective (e.g., by an alliance), later they can be exercised independently by each member of the collective (Pape \& Schmidt-Tank, 2004) - that is, each member of the collective can decide independently whether to fulfill or decline the subsequent larger-scale investment. For example, the alliance partners might collectively choose to preface a large-scale alliance initiative with a pilot project (Fawcett et al., 2008), such as developing a new recycling process and pilot testing its effects on a select region prior to agreeing to jointly develop a national network of recycling plants. The focus on joint (rather than unilateral) implementation distinguishes collective real options from similar concepts, such as incremental risk taking (Andriopoulos \& Lowe, 2000) and reciprocal exchange (Gouldner, 1960; Molm, Takahashi, \& Petersen, 2000). While both are additional paths to managing social uncertainty, incremental risk taking (Dunbar, Neufeld, Libow, Cohen, \& Foley, 1997) and reciprocal exchange (Komorita, Chan, \& Parks, 1993) are actions undertaken by an individual independent of other alliance partners. The acquisition of collective real options, in contrast, represents coordinated action among alliance partners, ${ }^{4}$

\footnotetext{
${ }^{4}$ Reciprocial exchange can involve negotiated exchange, where exchange partners create an agreement that "specifies the benefits that each actor will receive from the exchange" (Molm, 2010: 122), and these benefits can flow bilaterally (Molm, 2003). Negotiated exchange is complementary to collective real options. Resources are jointly invested into the relationship, strengthening the level of trust among the partners. However, what distinguishes collective real options from a negotiated-exchange strategy is the presence of
}

and it is this coordinated action that provides the opportunity to reduce social uncertainty in the alliance.

The second difference between collective real options and traditional real option concepts relates to the timing and benefits provided. Previous theorizing on time-to-build real options posits that their benefits are not realized until after the pilot venture is completed and that these benefits entail mitigating environmental uncertainty (Majd \& Pindyck, 1987). However, as suggested by Dixit and Pindyck (1994) and Li et al. (2007), collective real options provide social information as well as environmental information. Social information can surface prior to the completion of the pilot venture. It is the uncovering of information about the intentions, reliability, and commitment of alliance partners during the pilot project that enables collective real options to change how alliance partners perceive each other. For example, empirical work on technology outsourcing shows that alliance partners jointly may make small initial investments toward alliance initiatives to uncover more information about each other's intentions before committing large amounts of resources to the alliance (van de Vrande, Vanhaverbeke, \& Duysters, 2009). This refocusing of the benefits of real options from managing environmental uncertainty to managing social uncertainty distinguishes collective real options from similar concepts, such as contingency strategies (Nielsen, 1988) and contingent contracts (Bazerman \& Gillespie, 1999), both of which are concerned with managing environmental uncertainty (Laaksonen, Jarimo, \& Kulmala, 2009).

Collective real options bridge structural and motivational approaches to create a hybrid so-

social uncertainty (or risk of nonreciprocity; Lawler, 2001; Molm, Collett, \& Schaefer, 2007). Similar to other traditional structural solutions (such as contracting and self-enforcing commitments), negotiated exchange involves "agreements that are strictly binding ... they automatically produce the benefits agreed upon" (Molm et al., 2007: 209), resulting in "the risk [or perceived vulnerability] of non-reciprocity [being] eliminated" (2007: 212). Without social uncertainty, beliefs about another's motives and intentions (i.e., trustworthiness) are difficult to form, leaving room for suspicion when the ability to enforce agreement ends or loopholes are discovered (Malhotra \& Lumineau, 2011; Malhotra \& Murnighan, 2002). Thus, the collective real option framework complements negotiated exchange (and other structural solutions) and offers an alternative avenue for alliance partners to increase mutual cooperation. 
lution to alliance governance. As a structural solution, collective real options change the incentives of alliance participation by lowering the costs of cooperation (rather than by increasing the costs of defecting, as other structural solutions do): large-scale alliance participation is buffered by an initial less-costly (pilot project) initiative. As a motivational solution, collective real options reveal-through pilot project investment behaviors-alliance partners' integrity, reliability, and commitment. By credibly signaling intent in the pilot project, alliance partners influence how others perceive them through actions and not just words.

\section{Collective Real Options and Small Wins}

Using collective real options to manage social uncertainty can best be understood as an important opportunity for a relational small win. Small wins are "concrete, complete, implemented outcome[s] of moderate importance" (Weick, 1984: 43), and they represent an opportunity for alliance partners to see (preview) the potential value of successful cooperation.

The small wins framework derives from the observation that most organizing efforts-for example, alliance initiatives-are high in complexity and uncertainty about both the intentions of others and the outcomes of mutual cooperation (Weick, 1984). For instance, the complexity of alliance partner coordination and uncertainty about partner follow-through on promised material and intellectual contributions are ever-present barriers to developing successful interfirm initiatives (Wilson \& Douglas, 2007). The high complexity and uncertainty surrounding large-scale collective investment can lead an alliance partner to be fearful about whether the other partners will cooperate. This fear often leads individuals to forgo cooperative initiatives-to defensively defect (Hobfoll, 1989). The small wins framework suggests that breaking a large-scale collective effort up into multiple smaller collective efforts reduces the task's complexity and perceived uncertainty (Weick, 1984). This, in turn, lowers the barrier for alliance partners to invest resources in an initial smaller collective effort. The smaller collective effort then provides the opportunity to achieve small wins.

The smaller (pilot project) collective effort, in fact, can provide two kinds of small wins: a small win demonstrating the viability of the larger-scale cooperative effort (i.e., "proof-ofconcept"; McAdam, McAdam, Galbraith, \& Miller, 2010) and a small win demonstrating the trustworthiness of alliance partners. Exploring the viability of a collective venture reduces environmental uncertainty, while exploring the trustworthiness of alliance partners reduces social uncertainty. Because the success of the small initial investment lowers the environmental and social uncertainty barriers to subsequent larger-scale alliance investments, the achievement of these small wins propels the exchange parties forward to invest in largerscale collective efforts (Reay, Golden-Biddle, \& Germann, 2006). Whereas traditional research on real options focuses on achieving small wins to mitigate environmental uncertainty, this article shifts the focus to understanding how collective real options reduce social uncertainty by influencing the development of trust.

\section{Relational Small Wins and Trust}

Relational small wins encourage subsequent larger-scale cooperation in alliances by fostering trust and thereby reducing social uncertainty. Trust is an individual's "expectations, assumptions or beliefs about the likelihood that another's future actions will be beneficial, favorable or at least not detrimental" to the individual (Robinson, 1996: 576), and it is formed through social interaction. When individuals interact, they bring with them values about what behaviors are appropriate in a relationship, along with expectations about behaviors they want from others, and they experience emotions based on how other individuals treat them (Jones \& George, 1998). Through social interaction each individual attempts to (1) assess the perceived values of the other ("Does the individual have integrity?"), (2) know whether others have met his or her expectations ("Did they cooperate or not?"), and (3) use his or her current emotions and moods as indicators to assess the quality of the relationships ("How do I feel based on how others treated me?").

Research on trust in alliances references the real options research literature as holding promise in understanding how alliance partners build trust (Das \& Teng, 1998). Trust evolves through interaction among individuals when values are perceived as congruent, positive ex- 
pectations are met, and positive emotions and moods are experienced based on how an individual has been treated by others (Jones \& George, 1998). Applying this logic to strategic alliances, collective real options enable alliance partners to uncover information about the reliability, integrity, and commitment of one another. When the relational small wins are realized, alliance partners know that everyone else is reliable and committed to alliance success. As a consequence, the alliance partners become more trusting of one another.

Lewicki, McAllister, and Bies (1998) suggest that trust should develop among alliance partners as a function of the nature of their experience in acquiring the collective real option. How the alliance experience, when acquiring a collective real option, influences future cooperation can best be seen through the lens of vulnerability.

\section{Trust and Perceived Vulnerability}

Vulnerability has been defined variously as an individual's biased assessment of a risky situation (Cho \& Lee, 2006), composed of the degree of variability in the outcome of the purchase (or investment; Cox, 1967) and the amount of resources that can be lost (Cunningham, 1967); as an individual's assessed probability of an investment's success and the confidence in that assessment (Sitkin \& Pablo, 1992; Sitkin \& Weingart, 1995); and as a function of the social environment and the extent to which an individual believes his or her resources are in danger of being exploited by others (Meyerson et al., 1996). The recurring theme in these conceptualizations is that vulnerability is an individual's perception of risk subject to situational and social influences. Here we define perceived vulnerability as an individual's assessment of uncertainty about the future behavior of others and/or the environment.

Exposure is the amount an individual alliance partner must risk losing (in proportion to that partner's total wealth) to achieve the benefits from the investment (Cho \& Lee, 2006; Cunningham, 1967). For example, an alliance partner risking 90 percent of its total wealth toward the collective effort experiences relatively high exposure, while an alliance partner risking 10 percent of its total wealth toward the collective effort experiences relatively low exposure (Lubell, 2004). Thus, whereas perceived vulnerability is about the probability of failure of mutual cooperation in an alliance, exposure is concerned with how badly an alliance partner will be damaged if such a failure occurs. Exposure may be central to understanding how collective real options can impact trust formation even when mutual cooperation occurs in its acquisition.

In summary, collective real options enable alliance partners to find out more information about the social and task environments before undertaking full investment in an alliance. When mutual cooperation is successful in the acquisition of the collective real option, the alliance partners experience a relational small win. The achievement of a relational small win reduces the uncertainty inherent in how an alliance partner perceives its vulnerability in the alliance.

\section{MODELING REAL OPTIONS EFFECTS}

First we try, then we trust! (Sean Connery in the film Entrapment).

As suggested by the above quotation, collective real options enable alliance partners to "first try" to see if they can trust one another, prior to making full investments in the alliance. In this section we articulate a series of propositions modeling how collective real options influence trust formation in alliance relationships and, as a consequence, subsequent large-scale alliance investment. Propositions 1 through 3 constitute the base model. Successful mutual cooperation when the alliance acquires the real option provides a relational small win, thereby increasing trust among the alliance partners. The increase in trust among the alliance partners reduces the perceived vulnerability from social uncertainty, so (as a consequence) alliance partners should be more willing to cooperate by fully investing in the alliance. Propositions 4 through 7 extend the core model by considering how characteristics of the collective real option (i.e., exposure) and the alliance partners (i.e., reputation) influence trust formation. Figure 1 provides a conceptual roadmap outlining these relationships.

Two boundary conditions are necessary to understand the impact of collective real options 
FIGURE 1

A Conceptual Model of a Collective Real Options Approach to the Social Dilemma of Strategic Alliances

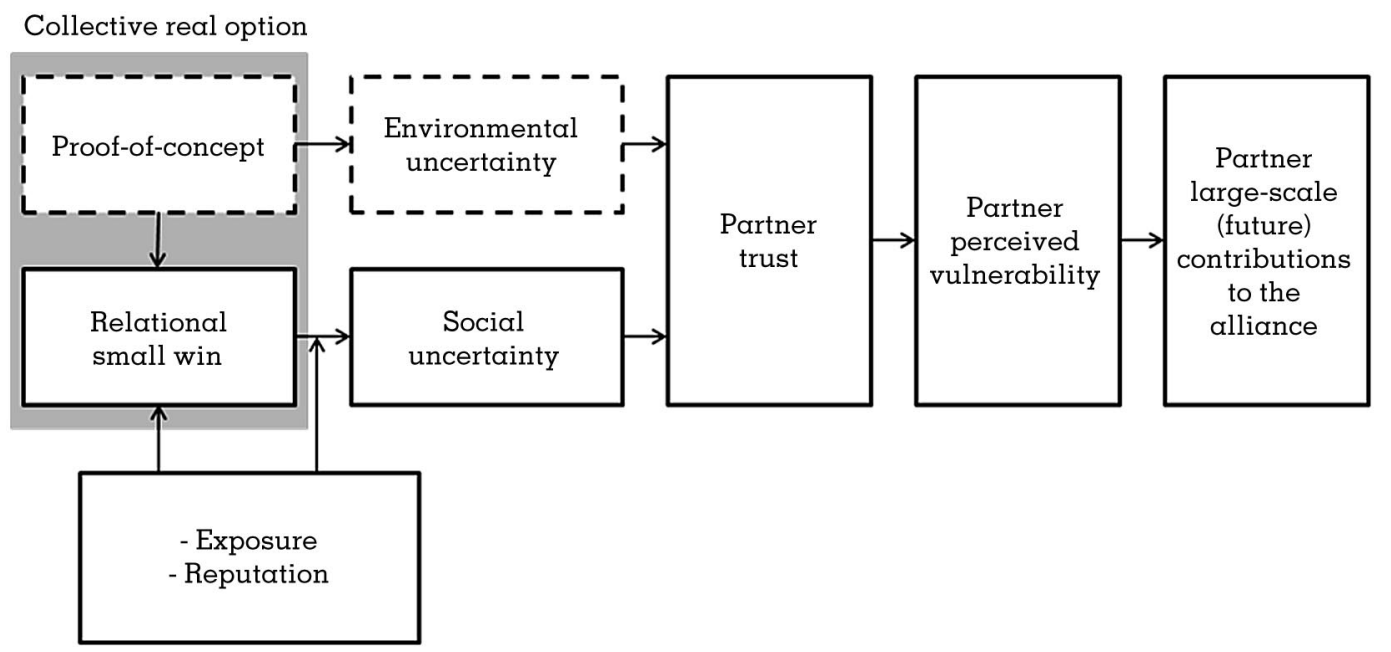

and the relational small wins they can produce. First, the attainment of a small win requires the external environment both to be promising and to provide the alliance partners a favorable return on the real option (assuming mutual cooperation occurs). Otherwise, the firms have an incentive to exit the venture by not exercising the option of further investment (Adner \& Levinthal, 2004). This first assumption stems from recent social dilemma research showing that social uncertainty and environmental influence are distinct determinants of alliance cooperation: individuals will defect in the presence of environmental uncertainty irrespective of how much they trust their alliance partners (McCarter et al., 2010).

Second, our model is based on the psychological approach to trust (see Lewicki, Tomlinson, \& Gillespie, 2006, for a review), which assumes that trust among individuals begins low (at the conceptual level of zero) and the first encounter among individuals acts as a validation opportunity regarding trustworthiness (Jones \& George, 1998). If the encounter is positive, then trust increases as a function of the amount of the risk embedded in the encounter. The psychological approach also assumes that trust is not monolithic across the breadth of the relationship among alliance partners. Lewicki and colleagues (1998) observed that relationships are complex and multifaceted. Thus, existing relationships may be composed of individuals who trust each other on some matters but not others. As suggested by Hardin (1993), individual A can trust individual $\mathrm{B}$ to do action $\mathrm{X}$ but not action $\mathrm{Y}$, because either action $\mathrm{Y}$ is different from action $\mathrm{X}$ or because previous experience has shown that individual B cannot (for whatever reason) do action Y. This insight is illustrated in Larson's (1992) case study of the formation of interfirm ties: although some alliance partners had considerable positive history with each other outside the alliance context, they nevertheless undertook a "trial phase" to prove each other's trustworthiness related to alliance activities. Drawing from this approach, our theorizing posits that, in relation to elements specific to the strategic alliance, prospective alliance partners begin with low trust. This assumption does not remove the possibility that the alliance partners share a positive history outside the alliance (as will be discussed later); it leaves room for the alliance partners to enlarge the breadth of their relationship through small wins germane to alliance initiatives.

\section{Relational Small Wins of Mutual Cooperation and Trust}

Successful mutual cooperation increases trust among alliance partners. When alliance partners invest in the small-scale alliance initiative, they acquire an opportunity to experience successful mutual cooperation in the form of a col- 
lective real option. Significantly, acquiring a collective real option is not necessarily a onetime event. Agreeing to invest in an initial small-scale project must be followed up with fulfillment of promised capital, personnel, and commitment throughout the time period of the pilot project (Robson et al., 2008).

The real options research literature holds promise for understanding how "incremental resource commitments" could increase trust among alliance partners (Das \& Teng, 1998: 504). An alliance's successful mutual cooperation in acquiring a collective real option creates an exchange history among the alliance partners (Gulati, 1995a). This exchange history entails alliance partners' uncovering one another's values, expectations, and feelings about each other (such as integrity, reliability, and commitment to the alliance)-all of which influence the formation of trust (Jones \& George, 1998; Poppo, Zhou, \& Sungmin, 2008). As a result, the "predictability" of alliance partners' future behavior increases (Weick, 1984) and trust (as a consequence) is enhanced (Sniezek, May, \& Sawyer, 1990; Vangen \& Huxham, 2003):

\begin{abstract}
Proposition 1: Alliances that experience the relational small wins of mutual cooperation by successfully acquiring collective real options will experience higher trust compared to alliances that do not experience relational small wins of mutual cooperation by successfully acquiring collective real options.
\end{abstract}

\section{Trust and Perceived Vulnerability}

Trust is a critical psychological factor in determining the level of perceived vulnerability that an exchange partner experiences in an alliance. When trust is high, social uncertainty about the future behavior of others is minimized (Kollock, 1994). A decrease in social uncertainty makes alliance partners less fearful that their investment will be lost because of free riding or defensive defection (Schnoke, 1991; Sniezek et al., 1990). Perceived vulnerability is therefore reduced among alliance partners. Trust will mediate the relationship between relational small wins of mutual cooperation in acquiring the collective real option and perceived vulnerability.
Proposition 2a: As trust among alliance partners increases, perceived vulnerability experienced by those alliance partners decreases.

Proposition 2b: Trust mediates the relationship between relational small wins and perceived vulnerability of alliance partners.

\section{Vulnerability and Investment in Strategic Alliances}

Perceived vulnerability negatively affects an alliance partner's willingness to contribute resources toward the alliance. In social dilemmas an individual experiences high perceived vulnerability from uncertainty (about others or the value of cooperation) and the fact that resources must be risked. Resource conservation theories maintain that when individuals perceive that their resources are threatened with a potentially irreversible loss, they experience stress and therefore seek to avoid the threat by selecting a course of action that minimizes the likelihood their resources will be lost (Hobfoll, 1998). Consumer purchasing theories make a similar prediction about individuals facing risky investments: high perceived risk (vulnerability) in an investment motivates individuals to engage in "risk reduction strategies"-one of which is avoiding the investment (Cox, 1967). In social dilemma terms, risk reduction likely equates to defecting (or undercontributing) toward the alliance public good.

Proposition 3: An alliance partner will be less likely to contribute toward the alliance's initiatives when perceived vulnerability is higher.

\section{Exposure and Trust Development}

Recent research on trust development in alliances suggests that it is not the length of the history among alliance partners that develops trust but, rather, the quality of that history $(\mathrm{Gu}-$ lati \& Sytch, 2008; Lewicki et al., 2006). Exposure when acquiring the collective real option may have a direct effect on whether a relational small win is achieved and what impact that relational small win has on trust development among alliance partners. 
High exposure in creating the collective real option may legislate against ever attempting a relational small win. Recent work on real options and organizational learning maintains that if trial-and-error learning (e.g., via a pilot project) is too risky (i.e., exposure is high), firms will be reluctant to invest in pilot projects (Fichman, 2004). Similarly, if acquiring a collective real option requires high levels of exposure, alliance partners may be particularly likely to experience higher vulnerability from social uncertainty (Cho \& Lee, 2006; Hobfoll, 1998). Experiencing heightened perceived vulnerability, alliance partners will be inclined to underinvest (or not invest at all) in the acquisition of the collective real option. As a consequence of this underinvestment, the opportunity for achieving the relational small win of mutual cooperation is less likely. The unsuccessful achievement of a relational small win when acquiring the collective real option will keep trust low among alliance partners. Trust will be low because the unsuccessful achievement of mutual cooperation will create a trust breach, decreasing an alliance partner's trust in the other partners' intentions to support the alliance (Lount, Zhong, Sivanathan, \& Murnighan, 2008; Stout, 2008).

Considering the potential negative outcome of high exposure, an initial strategy to elicit cooperation among alliance partners may be to ask for small investments (minimizing exposure) when acquiring the collective real option. However, low exposure when acquiring the collective real option may undermine the development of trust, even when the relational small win of mutual cooperation is realized in acquiring the collective real option. Molm et al. note that "both structural risk and trustworthy behaviors are necessary for the development of trust" (2007: 212). Indeed, extant trust research proposes that without "enough vulnerability" among exchange parties, trust cannot successfully form (Mayer, Davis, \& Schoorman, 1995; Ribstein, 2000). Empirical research on the "footin-the-door" technique supports this claim: getting individuals to make a small initial investment increases the likelihood they will comply with larger requests in the future, and future compliance increases when the initial request is moderate rather than low (Segilman, Bush, \& Kirsch, 1976). An explanation for this moderating effect of exposure on the relationship between relational small wins and trust can be found in attribution theory, which suggests that causal attributions for an individual's compliance to a request are a function of the request's perceived difficulty (Heider, 1958; Kelley, 1973). When alliance partners invest small amounts of resources toward the acquisition of a collective real option, that cooperation is more likely to be attributed to the low exposure of the request rather than to the commitment (or trustworthiness) of the alliance partners (Malhotra \& Murnighan, 2002).

Empirical results from experimental social psychology support this explanation of trust development. In the "trust game" Pillutla, Malhotra, and Murnighan (2003) found that large offers from the sender are attributed by receivers as signals of high trust while low offers are not. In other words, the extent to which an alliance partner risks exposure influences how committed to the alliance (and, thus, trustworthy) that alliance partner is perceived to be.

Proposition 4a: As exposure in acquiring the collective real option decreases, the likelihood of investment by alliance partners to realize a relational small win of mutual cooperation increases.

Proposition 4b: Exposure in acquiring the collective real option will moderate the relationship between relational small wins and trust such that relational small wins of mutual cooperation will have a less beneficial effect on trust among alliance partners when exposure is low than when exposure is high.

\section{Partner Reputation and Trust Development}

The previous section considered how a characteristic of the collective real option-exposure required of alliance partners-influences an alliance partner's cooperation, when acquiring the collective real option, and trust formation. A characteristic of the alliance partners themselves-reputation-also may impact both collective real option acquisition and its effects on trust development. Reputation refers to information about how an alliance partner performed previously in separate ventures (Shane \& Cable, 2002). Reputational information is a powerful so- 
cial-structural element of alliance relationships (Gulati, 1995b) and can be acquired either firsthand, through direct social encounters (Anderson \& Shirako, 2008), or secondhand, through social networks (Kogut, Shan, \& Walker, 1992).

Reputation should directly influence cooperation in alliance initiatives because it provides alliance partners with information about one another's values, expectations, and feelings (Jones \& George, 1998) and thereby signals alliance partners about the predictability of each other's future behavior (Bolton, Katok, \& Ockenfels, 2005; Kollock, 1994), thus reducing social uncertainty. Individuals who perceive one another as having a positive (cooperative) reputation are more likely to cooperate in situations requiring trust (Weber, Malhotra, \& Murnighan, 2005). Bohnet and Huck (2004) found that allowing participants to know their current partners' history of cooperation with previous partners (and that the history was positive) increased their willingness to initially cooperate. This empirical finding suggests that other partners' reputations should influence an alliance partner's willingness to acquire a collective real option.

Proposition 5: The positive reputations of other alliance partners increase the likelihood of investment by alliance partners to realize a relational small win of mutual cooperation.

Reputation may also indirectly influence trust formation, when attempting relational small wins, by buffering the impact of real option success or failure on subsequent trust development and alliance partner investments in alliance activities. Kelley and Michela's (1980) review of attribution theory is one of the first to suggest that an individual's reputation can influence how others attribute the cause of the individual's current behavior. Alliance partners may be buffered (positively or negatively) by their reputations, which may impact how they are perceived after small wins are attempted (Jones, Jones, \& Little, 2000). Similar to our discussion about the moderating effect of exposure, collective members often seek causal explanations for the outcomes of their collective efforts (Stouten, De Cremer, \& van Dijk, 2006; Weber, Camerer, Rottenstreich, \& Knez, 2001). If reputation among alliance partners is positive (from a previous history of cooperative behavior), then successful achievement of relational small wins will more likely be treated as confirmation of the reliability and trustworthiness of the alliance partners. This should enhance trust more than if partners initially have little or no reputational information to draw on.

\section{Proposition 6: Achieving relational small wins will have more of an effect on trust among alliance partners when reputations are positive than when there is no reputation information.}

What happens when alliance partners fail to achieve mutual cooperation? Alliance partner reputation may act as a buffer between collective failure and potential distrust among alliance partners. If an alliance partner has a positive reputation (history of being cooperative), defection would likely be attributed to an external cause, such as the riskiness or difficulty of cooperating, and the defecting alliance partner would less likely be viewed as untrustworthy by the other partner(s). In support of this position, Lount et al. (2008) found that participants in an iterated prisoner's dilemma who experienced partner defection after a history of partner cooperation were more willing to continue to trust their partner, suggesting they attributed that defection to something external.

Proposition 7: Failure to achieve small wins will have less of an effect on trust among alliance partners when reputations are positive than when there is no reputation information.

In summary, a collective real option creates the opportunity for alliances to achieve relational small wins of mutual cooperation. These relational small wins build trust, and high trust increases on alliance partner's willingness to contribute toward the alliance by lowering that partner's perceived vulnerability. Exposure, when acquiring the collective real option, directly affects the likelihood of mutual cooperation and also, when a small win is achieved, moderates the relationship between mutual cooperation and the development of trust among alliance partners. Reputation of the alliance partners directly affects the likelihood of mutual cooperation and also moderates the relationship between mutual cooperation success or failure and the development of trust among alliance partners. 


\section{DISCUSSION AND CONCLUSIONS}

Past research on real options has focused primarily on individual strategies for mitigating environmental uncertainty. Here we draw from the small wins literature and social dilemma literature to introduce the concept of collective real options, and we explore how collective real options may impact the management of social uncertainty in strategic alliance social dilemmas.

\section{Theoretical Implications}

A real options approach to navigating strategic alliance social dilemmas provides on understanding of how an alliance may be structured to manage not only how exchange partners think about the alliance but also how they think about each other (Kollock, 1998; Zeng \& Chen, 2003). Collective real options enable alliance partners to hedge risk from the market environment and to hedge risk from the social environment by allowing them to "first try, then trust" each other on larger alliance initiatives. In trying, alliance partners credibly reveal their cooperative intentions through actions (i.e., investing in the collective real option), and these actions affect how other alliance partners perceive them.

Using collective real options to "test the waters" of cooperating with alliance partners may be particularly useful in cases where intangible contributions will have a lot to say in determining whether the alliance succeeds or fails. Related governance approaches, such as negotiated exchange (e.g., Molm, 2010), may be good at creating enforcement mechanisms for concrete alliance contributions that can be monitored and confirmed, but it is difficult to legislate trying hard and thinking hard. As suggested by Sesil, when it is "difficult to monitor effort," a mechanism that signals cooperative intent is helpful to increase trust and cooperation among alliance partners (2006: 593). For such resources-and particularly when those resources will partly determine whether an alliance succeeds-alliance partners may need the proof of a relational small win to feel comfortable going the distance with other alliance partners.

Collective real options may also prove particularly useful in revealing whether all alliance partners are on the same page in terms of what it means to fulfill one's obligations to the alliance. Tenbrunsel and Northcraft (2010) note that not all defection in alliances need be intentional. Any partner brings to an alliance idiosyncratic views of what it means to be a "good partner" and may be fulfilling its own views even while not fulfilling what other alliance partners think is fair. Furthermore, although a "logic of appropriateness" typically governs social exchanges (e.g., March, 1994; McCarter, Budescu, \& Scheffron, 2011), which logic of appropriateness applies in a particular situation may differ among partners, depending on how they frame the alliance activity (e.g., as investing versus cooperating). For these reasons talk not only may be cheap but may also insufficiently reveal what is in the minds of alliance partners. Happily, collective real options may provide both an opportunity to reveal differences of opinion and perspective along these lines and a forum for reconciling those differences to form a more perfect union during any later, larger collaboration.

Given these concerns, it should not be surprising that alliance research has discovered a period of "ambivalence" existing among partners in the early stages of an alliance (Gulati \& Sytch, 2008). This period of ambivalence may well reflect a tension within alliance partners to approach the value creation opportunities alliances promise but to avoid the vulnerability that alliance cooperation inevitability entails. The attribution perspective on exposure and trust development explored here suggests that erring on the side of too much caution-by avoiding any vulnerability in early-stage alliance initiatives-may doom an alliance to never develop enough trust. Alliances that use collective real options as a means to develop trust, therefore, must search out the happy medium whereby alliance partners are exposed enough to experience the development of trust, but not so much as to discourage investment in the collective real option. Because collective real options reveal the true character of alliance partners, the very willingness of partners to acquire a collective real option-and thus risk revealing their character-suggests something about their intent to cooperate. This is not to suggest that $a$ partner could not fake collaborative posture during a pilot venture with the intention of behaving more opportunistically later. However, the larger the exposure on alliance partner has in 
the pilot venture, perhaps the more likely that partner's true character will be revealed.

Our analysis of the impact of collective real options also offers a new perspective on the role of reputations in alliances. Previous research on trust and cooperation has highlighted the main effects of reputations on trust (Bohnet \& Huck, 2004; Das \& Teng, 2001; Weber et al., 2005). Our arguments shift the focus of reputations to their indirect effects on partners' interpretations of success and failure of pilot ventures. Specifically, a positive reputation may serve to enhance the impact of cooperative behaviors on trust development when relational small wins are achieved, and it may buffer on alliance partner from being viewed as untrustworthy when small wins are not achieved. Significantly, any discussion of reputations in alliances begs some interesting levels-of-analysis issues, such as whether alliances can trust, or whether trust is really the province of individual decision makers. This becomes particularly important when we contemplate the possibility that reputation within a multiple-actor partner may not be homogeneous or that any partner's reputation may not be homogeneously perceived within an alliance, or even within other partners (Arend, 2009). Although beyond the scope of this article, such questions bring numbers into the discussion-both the number of partners in the alliance and the number of actors within any "partner"-since trust becomes a harder nut to crack as group size increases (e.g., Huck \& Lunser, 2010), probably on both dimensions.

Another critical contribution of this article is that it redirects scholarly conversation about alliance governance, from managing opportunism to managing defensive perceptions. Previous research, such as game-theoretic and transaction cost approaches to alliance management, has emphasized governing alliances to avoid offensive (opportunistic) defection (Heide \& Miner, 1992; Parkhe, 1993). Recent research on applying the social dilemma paradigm to alliances has echoed this emphasis by focusing on structural and motivational strategies that help protect "an overtrusting partner [from being an] easy target for exploitation by its greedy partners" (Zeng \& Chen, 2003: 588). This does not suggest that research on alliance social dilemmas ignores defensive defection. Indeed, Zeng and Chen (2003) encouraged trust building as a means of alleviating fear of opportunism. How- ever, McCarter and Northcraft (2007) suggest that even if an alliance is structured to remove offensive defection, such as by making all partners irreplaceable, an alliance partner may still doubt others' ability and willingness to cooperate and defect defensively. This insight reminds us that alliance management is not only about reducing opportunism but also about a partner reducing other partners' fear they will be made the "sucker" (Schnoke, 1991). Whereas recent alliance research considers perceptions when examining alliance governance (McCarter \& Northcraft, 2007), our model extends this thinking by using real options to show one way to manage defensive perceptions among alliance partners. Rather than avoiding opportunism by others, the emphasis of this approach is avoiding missed opportunities to create value by lowering the barriers to collective cooperation.

Solutions to managing social uncertainty might be applicable to strategic alliances where offensive defection is either possible or not. Our model applies to both cases. If the alliance is structured to allow free riding, collective real options enable familiarity among alliance partners and the achievement of shared benefits, thereby reducing the temptation to opportunistically hurt others and potentially kill the golden goose (Pruitt \& Kimmel, 1977). If on alliance structure makes free riding impossible, then collective real options enable alliance partners to garner trust and show both the motivation and the capability to cooperate as the stakes grow (Chen, 1996).

This article also provides several contributions to the study of real options. First, previous research has examined how real options manage external market environments and mitigate environmental uncertainty to encourage alliance success (Kogut, 1991). Here we show how real options can manage and reduce social uncertainty among alliance partners, thereby answering the call from scholars to understand how real options affect the social, as well as the exogenous, environment (Busby \& Pitts, 1997; Foote \& Folta, 2002). In acquiring the collective real option, alliance partners may uncover each other's intentions before significant investments are made. This insight redirects discussion of real options from managing the external market environment to navigating the internal social environment. 
Second, the real options literature has primarily examined how firms individually use real options in investments (Li et al., 2007). However, we emphasize that collective real options may be used strategically in collective efforts: alliance partners can jointly acquire a collective real option (such as undertaking a pilot project) while retaining the unilateral ability to exit should the future look relationally (or environmentally) grim. Indeed, collective real options can increase trust and foster cooperation by decreasing perceived vulnerability among alliance partners, and thus lowering the barrier to at least try to cooperate.

A third contribution to the real options literature is challenging the premise that time-tobuild real option benefits cannot be realized until after all stages of investment have been made and that these benefits are either financial or physical in nature (Majd \& Pindyck, 1987). This assumption may hold if the benefits of real options are only monetary (Trigeorgis, 1999). However, our model considers the relational benefits (e.g., information about other alliance partners' cooperative intent)-in addition to the economic benefits (e.g., monetary returns from the pilot project) - that become available before full investment is required. Considering that with whom we invest can be just as important as in what we invest (Adabor, 2006), the relational benefits of collective real options should provide decision makers invaluable information that influences both their social and investment behavior.

This article advances the idea of small wins as well. While Weick's (1984) seminal framework provides explanations for how largescale alliance initiatives are achieved (Reay et al., 2006), it gives little consideration to how the size of the small win makes a difference in motivating cooperation. Weick acknowledges that wins can be "arranged on a continuum" (1984: 43) in different orders of magnitude. We expand on this observation, explaining how and why the size of the small win matters. If the small win is too small, then alliance partners may not be convinced that future cooperation will result in large-scale benefits; if too large a small win is attempted, vulnerability may discourage prospective alliance partners from ever pursuing it.

\section{Managerial Implications}

This article also provides several implications for managers. Primarily, collective real options offer alternatives for alliance governance. Consider, for example, the often proposed remedy to reduce social uncertainty in alliance efforts: external regulation (e.g., government regulation). While external regulators can increase cooperation (Olson, 1965), they also can introduce additional conflicts of interest and ulterior motives among collective partners that undermine the very cooperation these regulations were meant to create (Crowe, 1969; Tenbrunsel \& Messick, 1999). A collective real options approach may be particularly attractive to collectives for addressing social dilemmas because it retains control within the group and is self-perpetuating through small wins, while still avoiding the risks of unilateral cooperation.

An example of an alliance seeking to avoid third-party intervention through the use of collective real options is the Suwannee River Partnership in northern Florida, formed to encourage Florida farmers to voluntarily cooperate to reduce water pollution and avoid government intervention. These formers faced a social dilemma since each farmer was tempted to defect by letting other neighboring formers incur the costs of mitigating water pollution-but if everyone chose this strategy, water pollution would continue and government sanctions would be imposed. To encourage cooperation among the hesitant farmers, the partnership organized joint small-scale demonstration projects to build trust among the farmers so that everyone would cooperate on a larger scalethat is, adopting best practices that would cost an individual form hundreds of thousands of dollars to implement (Dedekorkut, 2005). The successful utilization of collective real options among the farmers meant farms and local organizations retained control.

A second managerial implication concerns what management scholars transfer to management practice (Van de Ven, 2007). For decades the discussion in business periodicals has been primarily about leveraging real options to reduce environmental uncertainty (Copeland \& Tufano, 2004; Kogut \& Kulatilaka, 1994). While informative for managers, this myopic focus has been unfortunate, considering that social uncertainty is, perhaps, the most commonly discussed 
hazard to effective collective action (Olson, 2002; Williamson, 1991). This article suggests that not all small wins are created equal. Rather, the larger the small win, the greater the likelihood that individuals will push forward to achieve something greater. However, large small wins can only be achieved at the risk of higher levels of exposure, making alliance partners less likely to cooperate and more likely to suspect that their partners will not fully cooperate either. In short, there is an optimal mid range of risk that alliances must find to have enough exposure to garner trust but not too much to scare away prospective alliance partners.

\section{Future Directions}

The model and propositions offered here provide several avenues for future research. This article addresses how collective real options influence trust and cooperation in strategic alliance initiatives. An unaddressed issue that remains is what role alliance size (number of alliance partners) plays in the dynamics described in this model. When collective action entails a large number of partners (often beyond two parties), unilateral strategies, such as direct reciprocal exchange and sanctioning, become difficult to implement because of increased monitoring costs and complexity (Boyd \& Richerson, 1988; Carpenter, 2007; Molm, 1994). Using collective real options, in contrast, requires coordinated actions that allow partners to exit the alliance should large-scale collective action look grim. This contrast suggests that as the number of alliance partners increases, so should the likelihood of adopting a collective real options strategy.

Understanding the effects of collective real options internal to the alliance raises the question, "What effects do collective real options have on external alliance relationships?" Our model focuses on outcomes directly related to the achievement of small wins and does not consider the potential indirect effects of (not) achieving a small win. This narrower focus may initially suggest that using a collective real option is always the best approach in alliances, but this actually may not always be the case. For instance, what we experience in one instance can spill over into other similar instances (Byrne \& Clore, 1970; Messick, 1999). If an alliance partner experiences a breach in trust with a set of partners using a collective real option, then that partner may carry that fear into other relationships with the same-or completely different-alliance partners. Future research may consider whether trust breaches and successful trust building using collective real options carry over to other related cooperative ventures and how long these carryover effects persist.

A third issue concerns how real options may be used to signal participants and outside observers of alliances. Research has long focused on the role of signaling for fostering cooperation (Kollock, 1998). Signaling is important in cooperative efforts (especially where verbal communication is not possible) because it reduces other individuals' social uncertainty and breeds trust. While suggesting how collective real options can be a signaling mechanism, the current model is limited in terms of who is being signaled. The model focuses only on those directly involved in the social dilemma being signaled about the intentions of their alliance partners. Research on social movements (a form of alliance) reminds us that the composition of collectives facing social uncertainty is not static: newcomers often are solicited to join the cause or hold out until they become assured that largescale cooperation is possible (Whittier, 1997; Zald \& McCarthy, 1987). In future research scholars may wish to examine how using real options can serve as a mechanism for signaling and facilitating cooperation among active participators and outside observers who are considering joining the cause.

It has been said that "what we accomplish together will benefit many" (Stewart, 2001: 1), and in many ways the fruits of collaboration are what separate the civilized from the savages. Unfortunately, the benefits of working together can be elusive, because alliances create social dilemmas in which individuals withhold cooperation when they perceive themselves as potentially vulnerable to others' opportunistic behavior (Williamson, 1991), and there is rarely a "Leviathan" (Hobbes, 1907/1651) handy to enforce cooperative intent. Drawing from the social dilemma, real options, and small wins literature, this article presents a hybrid approach to mitigating social uncertainty in alliance governance. Collective real options provide alliance partners the opportunity to first try and then trust each other before undertaking large-scale (and thus large-exposure) cooperative initia- 
tives. Using a collective real options approach enables us to explain and predict how an appropriately sized small win is the first step in completing the long journey toward having alliance partners successfully working together.

\section{REFERENCES}

Adabor, H. 2006. The role of personal relationships in interfirm alliances: Benefits, dysfunctions, and some suggestions. Business Horizons, 49: 473-486.

Adner, R., \& Levinthal, D. 2004. What is not a real option: Considering boundaries for the application of real options to business strategy. Academy of Management Review, 29: 74-85.

Agarwal, R., Croson, R., \& Mahoney, J. T. 2010. The role of incentives and communication in strategic alliances: An experimental investigation. Strategic Management Journal, 31: 413-437.

Anderson, C., \& Shirako, A. 2008. Are individuals' reputations related to their history of behavior? Journal of Personality and Social Psychology, 94: 320-333.

Andriopoulos, C., \& Lowe, A. 2000. Enhancing organisational creativity: The process of perpetual challenging. Management Decision, 38: 734-742.

Arend, R. J. 2009. Reputation for cooperation: Contingent benefits in alliance activity. Strategic Management Journal, 30: 371-385.

Bazerman, M. H., \& Gillespie, J. J. 1999. Betting on the future: The virtues of contingent contracts. Harvard Business Review, 77(5): 155-160.

Bohnet, I., \& Huck, S. 2004. Repetition and reputation: Implications for trust and trustworthiness when institutions change. American Economic Review, 94: 362-366.

Bolton, G. E., Katok, E., \& Ockenfels, A. 2005. Cooperation among strangers with limited information about reputation. Journal of Public Economics, 89: 1457-1468.

Bowman, E. H., \& Hurry, D. 1993. Strategy through the option lens: An integrated view of resource investments and the incremental-choice process. Academy of Management Review, 18: 760-782.

Bowman, E. H., \& Moskowitz, G. T. 2001. Real options analysis and strategic decision making. Organization Science, 12: 772-777.

Boyd, R., \& Richerson, P. J. 1988. The evolution of reciprocity and sizable groups. Journal of Theoretical Biology, 132: 337-356.

Brandenburger, A. M., \& Nalebuff, B. J. 1996. Co-opetition. New York: Doubleday.

Busby, J. S., \& Pitts, C. 1997. Real options in practice. Management Accounting Research, 8: 169-186.

Byrne, D., \& Clore, G. L. 1970. A reinforcement model of evaluative processes. Personality: An International Journal, l: 103-128.
Carpenter, J. P. 2007. Punishing free-riders: How group size affects mutual monitoring and the provision of public goods. Games and Economic Behavior, 60: 31-51.

Chen, M.-J. 1996. Competitor analysis and interfirm rivalry: Toward a theoretical integration. Academy of Management Review, 21: 100-134.

Cho, J., \& Lee, J. 2006. An integrated model of risk and riskreducing strategies. Journal of Business Research, 59: 112-120.

Copeland, T., \& Tufano, P. 2004. A real-world way to manage real options. Harvard Business Review, 82(3): 90-99.

Cornes, R., \& Sandler, T. 1996. The theory of externalities, public goods, and club goods (2nd ed.). Cambridge: Cambridge University Press.

Cox, D. F. 1967. Risk handling in consumer behavior: An intensive study of two cases. In D. F. Cox (Ed.), Risk taking and information handling in consumer behavior: 34-81. Cambridge, MA: Harvard University Press.

Crawford, V. 1998. A survey of experiments on communication via cheap talk. Journal of Economic Theory, 78: 286298.

Crowe, B. L. 1969. The tragedy of the commons revisited. Science, 166: 1103-1107.

Cunningham, S. 1967. The major dimensions of perceived risk. In D. F. Cox (Ed.), Risk taking and information handling in consumer behavior: 82-108. Cambridge, MA: Harvard University Press.

Das, T. K., \& Teng, B.-S. 1996. Risk types and the inter-firm alliance structures. Journal of Management Studies, 33: 827-843.

Das, T. K., \& Teng, B.-S. 1998. Between trust and control: Developing confidence in partner cooperation in alliances. Academy of Management Review, 23: 491-512.

Das, T. K., \& Teng, B.-S. 2000. A resource-based theory of strategic alliances. Journal of Management, 26: 31-62.

Das, T. K., \& Teng, B.-S. 2001. Trust, control, and risk in strategic alliances: An integrated framework. Organization Studies, 22: 251-283.

Das, T. K., \& Teng, B.-S. 2002. Alliance constellations: A social exchange perspective. Academy of Management Review, 27: 445-456.

Dawes, R. M. 1980. Social dilemmas. Annual Review of Psychology, 31: 169-193.

Dedekorkut, A. 2005. Suwannee River Partnership: Representation instead of regulation? In J. T. Scholz \& B. Stiftel (Eds.), Adaptive governance and water conflict: New institutions for collaborative planning: 52-63. Washington, DC: Resources for the Future.

Dixit, A., \& Pindyck, R. 1994. Investment under uncertainty. Princeton, NJ: Princeton University Press.

Dunbar, J. M., Neufeld, R. R., Libow, L. S., Cohen, C. E., \& Foley, W. J. 1997. Taking charge: The role of nursing administrators in removing restraints. Journal of Nursing Administration, 27(3): 42-48.

Dyer, J. H., \& Singh, H. 1998. The relational view: Cooperative strategy and sources of interorganizational competitive 
advantage. Academy of Management Review, 23: 660679.

Epley, N., Caruso, E., \& Bazerman, M. H. 2006. When perspective taking increases taking: Reactive egoism in social interaction. Journal of Personality and Social Psychology, 91: 872-889.

Farrell, J., \& Rabin, M. 1996. Cheap talk. Journal of Economic Perspectives, 10(3): 103-118.

Fawcett, S. E., Magnan, G., \& McCarter, M. W. 2008. Supply chain alliances and social dilemmas: Bridging the barriers that impede collaboration. International Journal of Procurement Management, 1: 318-342.

Fichman, R. G. 2004. Real options and IT platform adoption: Implications for theory and practice. Information Systems Research, 15: 132-154.

Foddy, M., Smithson, M., Schneider, S., \& Hogg, M. 1999. Resolving social dilemmas: Dynamics, structural, and intergroup aspects. Philadelphia: Psychology Press.

Folta, T. 1998. Governance and uncertainty: The trade-off between administrative control and commitment. Strategic Management Journal, 19: 1007-1028.

Folta, T. B., \& Miller, K. D. 2002. Real options in equity partnerships. Strategic Management Journal, 23: 77-88.

Foote, D. A., \& Folta, T. B. 2002. Temporary workers as real options. Human Resource Management Review, 12: 579597.

Gottschalg, O., \& Zollo, M. 2007. Interest alignment and competitive advantage. Academy of Management Review, 32: $418-437$.

Gouldner, A. W. 1960. The norm of reciprocity: A preliminary statement. American Sociological Review, 25: 161-178.

Gulati, R. 1995a. Does familiarity breed trust? The implications of repeated ties for contractual choice in alliances. Academy of Management Journal, 38: 85-112.

Gulati, R. 1995b. Social structure and alliance formation patterns: A longitudinal analysis. Administrative Science Quarterly, 40: 619-652.

Gulati, R. 1998. Alliances and networks. Strategic Management Journal, 19: 293-317.

Gulati, R., \& Sytch, M. 2008. Does familiarity breed trust? Revisiting the antecedents of trust. Managerial and Decision Economics, 29: 165-190.

Hardin, R. 1993. The street-level epistemology of trust. Politics \& Society, 21: 505-529.

Hardy, C., Phillips, N., \& Lawrence, T. B. 2003. Resources, knowledge and influence: The organizational effects of interorganizational collaboration. Journal of Management Studies, 40: 321-347.

Heide, J., \& Miner, A. 1992. The shadow of the future: Effects of anticipated interaction and frequency of contact on buyer-seller cooperation. Academy of Management Journal, 35: 265-291.

Heider, F. 1958. The psychology of interpersonal relations. New York: Wiley.

Hennart, J.-F. 1988. A transaction costs theory of equity joint ventures. Strategic Management Journal, 9: 361-374.
Hobbes, T. 1907. (First published in 1651.) Leviathan. New York: Routledge and Sons.

Hobfoll, S. 1989. Conservation of resources: A new attempt at conceptualizing stress. American Psychologist, 44: 513524 .

Hobfoll, S. 1998. Stress, culture, and community. London: Plenum Press.

Hoffman, A. J., Gillespie, J. J., Moore, D. A., Wade-Benzoni, K. A., Thompson, L. L., \& Bazerman, M. H. 1999. A mixedmotive perspective on the economics versus environmental debate. American Behavioral Scientist, 42: 12541276.

Huck, S., \& Lunser, G. K. 2010. Group reputations: An experimental foray. Journal of Economic Behavior \& Organization, 73: 153-157.

Jones, G. H., Jones, B. H., \& Little, P. 2000. Reputation as reservoir: Buffering against loss in times of economic crisis. Corporate Reputation Review, 3: 21-30.

Jones, G. R., \& George, J. M. 1998. The experience and evolution of trust: Implications for cooperation and teamwork. Academy of Management Review, 23: 531-546.

Kale, P., Dyer, J. H., \& Singh, H. 2002. Alliance capability, stock market response, and long-term alliance success: The role of the alliance function. Strategic Management Journal, 23: 747-767.

Kanter, R. 1994. Collaborative advantage: The art of alliances. Harvard Business Review, 72(4): 96-109.

Kaufman, C., \& Kerr, N. 1993. Small wins: Perceptual focus, efficacy, and cooperation in social dilemmas. Journal of Applied Social Psychology, 23: 3-20.

Kelley, H., \& Michela, J. 1980. Attribution theory and research. Annual Review of Psychology, 31: 457-501.

Kelley, H. H. 1973. The process of causal attribution. American Psychologist, 28: 107-128

Kim, Y. J., \& Sanders, G. L. 2002. Strategic actions in information technology investment based on real option theory. Decision Support Systems, 33: 1-11.

Kogut, B. 199l. Joint ventures and the option to expand and acquire. Management Science, 37: 19-33.

Kogut, B., \& Kulatilaka, N. 1994. Options thinking and platform investments: Investing in opportunity. California Management Review, 36(2): 52-71.

Kogut, B., Shan, W., \& Walker, G. 1992. Competitive cooperation in biotechnology: Learning through networks? In N. Nohria, \& R. Eccles (Eds.), Networks and organizations: Structure, form, and action: 348-381. Boston: Harvard Business School Press.

Kollock, P. 1994. The emergence of exchange structures: An experimental study of uncertainty, commitment, and trust. American Journal of Sociology, 100: 313-345.

Kollock, P. 1998. Social dilemmas: The anatomy of cooperation. Annual Review of Sociology, 24: 183-214.

Komorita, S. S., Chan, D. K., \& Parks, C. 1993. The effects of reward structure and reciprocity in social dilemmas. Journal of Experimental Social Psychology, 29: 252-267. 
Laaksonen, T., Jarimo, T., \& Kulmala, H. I. 2009. Cooperative strategies in customer-supplier relationships: The role of interfirm trust. International Journal of Production Economics, 120: 79-87.

Larson, A. 1992. Network dyads in entrepreneurial settings: A study of the governance of exchange relationships. Administrative Science Quarterly, 37: 76-104.

Lawler, R. J. 2001. An affect theory of social exchange. American Journal of Sociology, 107: 321-352.

Lewicki, R., McAllister, D., \& Bies, R. 1998. Trust and distrust: New relationships and realities. Academy of Management Review, 23: 439-458.

Lewicki, R., Tomlinson, E., \& Gillespie, N. 2006. Models of interpersonal trust development: Theoretical approaches, empirical evidence, and future directions. Journal of Management, 32: 991-1022.

Li, Y., James, B., Madhaven, R., \& Mahoney, J. T. 2007. Real options: Taking stock and looking ahead. Advances in Strategic Management, 24: 31-66.

Lichbach, M. I. 1996. The cooperator's dilemma. Ann Arbor: University of Michigan Press.

Liebrand, W. 1983. A classification of social dilemma games. Simulation \& Games, 14: 123-138.

Lount, R., Zhong, C., Sivanathan, N., \& Murnighan, J. 2008. Getting off on the wrong foot: The timing of a breach and the restoration of trust. Personality and Social Psychology Bulletin, 34: 1601-1612.

Lubell, M. 2004. Collaborative watershed management: A view from the grassroots. Policy Studies Journal, 32: 341363.

Luo, Y. 2007. Are joint venture partners more opportunistic in a more volatile environment? Strategic Management Journal, 28: 39-60.

Majd, S., \& Pindyck, R. 1987. Time to build, option value, and investment decisions. Journal of Financial Economics, 18: 7-27.

Malhotra, D. 2005. The effect of real options on trust and trustworthiness: The relevance of irrelevant alternatives. Paper presented at the IACM 18th Annual Conference, Seville, Spain.

Malhotra, D., \& Lumineau, F. In press. Trust and collaboration in the aftermath of conflict: The effects of contract structure. Academy of Management Journal.

Malhotra, D., \& Murnighan, J. K. 2002. The effects of contracts on interpersonal trust. Administrative Science Quarterly, 47: 534-559.

March, J. G. 1994. A primer of decision making. New York: Free Press.

Mayer, R. C., Davis, J. H., \& Schoorman, F. D. 1995. An integrative model of organizational trust. Academy of Management Review, 20: 709-734.

McAdam, M., McAdam, R., Galbraith, B., \& Miller, K. 2010. An exploratory study of principal investigator roles in UK university proof-of-concept processes: An absorptive capacity perspective. R\&D Management, 40: 455-473.
McCarter, M. W., Budescu, D. V., \& Scheffran, J. 2011. The give-or-take-some dilemma: An empirical investigation of a hybrid social dilemma. Organizational Behavior and Human Decision Processes, 116: 83-95.

McCarter, M. W., \& Northcraft, G. B. 2007. Happy together?: Insights and implications of viewing managed supply chains as a social dilemma. Journal of Operations Management, 25: 498-511.

McCarter, M. W., Rockmann, K. W., \& Northcraft, G. B. 2010. Is it even worth it? The effect of loss prospects in the outcome distribution of a public goods dilemma. Organizational Behavior and Human Decision Processes, 111: $1-12$.

Messick, D. M. 1999. Alternative logics for decision making in social settings. Journal of Economic Behavior and Organization, 39: 11-28.

Messick, D. M., Allison, S., \& Samuelson, C. 1988. Framing and communication effects on group partners' responses to environmental and social uncertainty. In S. Maital (Ed.), Applied behavioral economics, vol. 2: 677700. New York: University Press.

Messick, D. M., \& Brewer, M. 1983. Solving social dilemmas. Review of Personality and Social Psychology, 4: 11-44.

Meyerson, D., Weick, K., \& Kramer, R. 1996. Swift trust and temporary groups. In R. Kramer \& T. Tyler (Eds.), Trust in organizations: 166-195. London: Sage.

Miller, G. J. 1993. Managerial dilemmas: The political economy of hierarchy. Cambridge: Cambridge University Press.

Molm, L. D. 1994. Dependence and risk: Transforming the structure of social exchange. Social Psychology Quarterly, 57: 163-176.

Molm, L. D. 2003. Theoretical comparisons of forms of exchange. Sociological Theory, 21: 1-17.

Molm, L. D. 2010. The structure of reciprocity. Social Psychology Quarterly, 73: 119-131.

Molm, L. D., Collett, J. L., \& Schaefer, D. R. 2007. Building solidarity through generalized exchange: A theory of reciprocity. American Journal of Sociology, 113: 205-242.

Molm, L. D., Takahashi, N., \& Petersen, G. 2000. Risk and trust in social exchange: An experimental test of a classical proposition. American Journal of Sociology, 105: 13961427.

Monge, P. R., Fulk, J., Kalman, M. E., Flanagin, A. J., Parnassa, C., \& Rumsey, S. 1998. Production of collective action in alliance-based interorganizational communication and information systems. Organization Science, 9: 411-433.

$\mathrm{Mu}$, J. 2006. Real options analysis. Hoboken, NJ: Wiley.

Murray, E. A., \& Mahon, J. F. 1993. Strategic alliances: Gateway to the new Europe? Long Range Planning, 26: 102111.

Nielsen, R. P. 1988. Cooperative strategy. Strategic Management Journal, 9: 475-492.

Olson, L. A. 2002. Turning small wins into big victories. Information Week, January 28: 98. 
Olson, M. 1965. The logic of collective action. Cambridge, MA: Harvard University Press.

Pape, U., \& Schmidt-Tank, S. 2004. Valuing joint ventures using real options. ESCP-EAP Working paper No. 7, European School of Management, Paris.

Park, S. H., \& Ungson, G. R. 2001. Interfirm rivalry and managerial complexity: A conceptual framework of alliance failure. Organization Science, 12: 37-53.

Parkhe, A. 1993. Strategic alliance structuring: A game theoretic and transaction cost examination of interfirm cooperation. Academy of Management Journal, 36: 794829.

Pillutla, M., Malhotra, D., \& Murnighan, J. K. 2003. Attributions of trust and the calculus of reciprocity. Journal of Experimental Social Psychology, 39: 448-455.

Poppo, L., Zhou, K. Z., \& Sungmin, R. 2008. Alternative origins to interorganizational trust: An interdependence perspective on the shadow of the past and the shadow of the future. Organization Science, 19: 39-55.

Pruitt, D. G., \& Kimmel, M. J. 1977. Twenty years of experimental gaming: Critique, synthesis, and suggestions for the future. Annual Review of Psychology, 28: 363-392.

Reay, T., Golden-Biddle, K., \& Germann, K. 2006. Legitimizing a new role: Small wins and microprocesses of change. Academy of Management Journal, 49: 977-998.

Reuer, J. J., \& Tong, T. W. 2005. Real options in international joint ventures. Journal of Management, 31: 403-423.

Ribstein, L. 2000. Law v. trust. Working paper No. 00-38, George Mason University, Fairfax, VA.

Robinson, S. L. 1996. Trust and breach of the psychological contract. Administrative Science Quarterly, 41: 574-599.

Robson, M., Katsikeas, C., \& Bello, D. 2008. Drivers and performance outcomes of trust in international strategic alliances: The role of organizational complexity. Organization Science, 19: 647-665.

Rockmann, K., \& Northcraft, G. B. 2008. To be or not to be trusted: The influence of media richness on defection and deception. Organizational Behavior and Human Decision Processes, 107: 106-122.

Schnake, M. E. 1991. Equity in effort: The "sucker effect" in co-acting groups. Journal of Management, 17: 41-54.

Segilman, C., Bush, M., \& Kirsch, K. 1976. Relationship between compliance in the foot-in-the-door paradigm and the size of the first request. Journal of Personality and Social Psychology, 33: 517-520.

Sesil, J. C. 2006. Sharing decision-making and group incentives: The impact on performance. Economic and Industrial Democracy, 27: 587-607.

Shane, S., \& Cable, D. 2002. Network ties, reputation, and the financing of new ventures. Management Science, 48: 364-381.

Sing, T. F. 2002. Time to build options in construction processes. Construction Management and Economics, 20: $119-130$.
Sitkin, S. B., \& Pablo, A. L. 1992. Reconceptualizing the determinants of risk behavior. Academy of Management Review, 17: 9-38.

Sitkin, S. B., \& Roth, N. L. 1993. Explaining the limited effectiveness of legalistic "remedies" for trust/distrust. Organization Science, 4: 367-392.

Sitkin, S. B., \& Weingart, L. 1995. Determinants of risky decision-making behavior: $A$ test of the mediating role of risk perceptions and propensity. Academy of Management Journal, 38: 1573-1592.

Smit, H. T. J., \& Trigeorgis, L. 2004. Strategic investment: Real options and games. Princeton, NJ: Princeton University Press.

Sniezek, J. A., May, D., \& Sawyer, J. 1990. Social uncertainty and interdependence: A study of resource allocation decisions in groups. Organizational Behavior and $\mathrm{Hu}$ man Decision Processes, 46: 155-180.

Spekman, R. E., Isabella, L. A., MacAvoy, T. C., \& Forbes, T. 1996. Creating strategic alliances which endure. Long Range Planning, 29: 346-357.

Stewart, L. 200l. Food pantry workers gives thanks. Daily Herald, November, 19: Al.

Stout, L. A. 2008. The investor confidence game. Research paper No. 02-18, School of Law, UCLA.

Stouten, J., De Cremer, D., \& van Dijk, E. 2006. Violating equality in social dilemmas: Emotional and retributive reactions as a function of trust, attribution, and honesty. Personality and Social Psychology Bulletin, 32: 894-906.

Telser, L. G. 1980. A theory of self-enforcing agreements. Journal of Business, 53: 27-44.

Tenbrunsel, A. E., \& Messick, D. M. 1999. Sanctioning systems, decision frames, and cooperation. Administrative Science Quarterly, 44: 684-707.

Tenbrunsel, A. E., \& Northcraft, G. B. 2010. In the eye of the beholder: Payoff structures and decision frames in social dilemmas. In R. Kramer, A. E. Tenbrunsel, \& M. H. Bazerman (Eds.), Social decision making: Social dilemmas, social values, and ethical judgments: 95-115. New York: Psychology Press.

Tirole, J. 1996. A theory of collective reputation (with applications to the persistence of corruption and to firm quality). Review of Economic Studies, 63: 1-22.

Trigeorgis, L. 1999. Real options: A primer. In J. Alleman \& E. Naoam (Eds.), Real options: The new investment theory and its implications for telecommunications economics: 3-34. Boston: Kluwer Academic.

Van de Ven, A. H. 2007. Engaged scholarship: A guide for organizational and social research. New York: Oxford University Press.

van de Vrande, V., Vanhaverbeke, W., \& Duysters, G. 2009. External technology sourcing: The effect of uncertainty on governance mode choice. Journal of Business Venturing, 24: 62-80.

Vangen, S., \& Huxham, C. 2003. Nurturing collaborative relations. Journal of Applied Behavioral Science, 39: 5-32. 
Weber, J., Malhotra, D., \& Murnighan, J. K. 2005. Normal acts of irrational trust: Motivated attributions and the trust development process. Research in Organizational Behavior, 26: 75-101.

Weber, R., Camerer, C., Rottenstreich, Y., \& Knez, M. 2001. The illusion of leadership: Misattribution of cause in coordination games. Organization Science, 12: 582-598.

Weick, K. 1984. Small wins: Redefining the scale of social problems. American Psychologist, 39: 40-49.

Whittier, N. 1997. Political generations, micro-cohorts, and the transformation of social movements. American Sociological Review, 62: 760-778.

Williamson, O. E. 1979. Transaction-cost economics: The governance of contractual relations. Journal of Law and Economics, 22: 233-261.

Williamson, O. E. 1983. Credible commitments: Using hostages to support exchange. American Economic Review, 73: $519-540$.
Williamson, O. E. 1991. Comparative economic organization. Administrative Science Quarterly, 36: 269-296.

Wilson, J., \& Douglas, E. 2007. Renewable energy gains still far off. Los Angeles Times, January 28: Cl.

Zaheer, A., \& Venkatraman, N. 1995. Relational governance as an interorganizational strategy: An empirical test of the role of trust in economic exchange. Strategic Management Journal, 16: 373-392.

Zald, M. N., \& McCarthy, J. C. 1987. Social movements in an organizational society. New Brunswick, NJ: Transaction.

Zeng, M., \& Chen, X.-P. 2003. Achieving cooperation in multiparty alliances: A social dilemma approach to partnership management. Academy of Management Review, 28: 587-605.

Ziedonis, A. A. 2007. Real options in technology licensing. Management Science, 53: 1618-1633.

Matthew W. McCarter (mccarter@chapman.edu) holds the Wang-Fradkin Assistant Professorship and is an assistant professor of management at the Argyros School of Business and Economics, Chapman University. He received his Ph.D. in business administration from the University of Illinois at Urbana-Champaign. His research interest is conflict management, which includes the study of social dilemmas, collaboration, cooperation, coordination, and relationship repair.

Joseph T. Mahoney (josephm@illinois.edu) is the Caterpillar Chair in Business and director of graduate studies in the Department of Business Administration in the College of Business at the University of Illinois at Urbana-Champaign. He received his Ph.D. in business economics from the Wharton School of Business at the University of Pennsylvania. His research interest is organizational economics, which includes transaction cost economics, resource-based and dynamic capabilities approaches, and property rights theory.

Gregory B. Northcraft (northcra@illinois.edu) is the Harry J. Gray Professor of Executive Leadership and associate dean of faculty for the College of Business at the University of Illinois at Urbana-Champaign. He received his Ph.D. in social psychology from Stanford University. His major research interests include collaboration in teams, conflict management, managerial decision making, and employee motivation and job design, particularly in high-technology manufacturing settings. 